\title{
TINGKAT AKSESIBILITAS PEJALAN KAKI (STUDI KASUS PEJALAN KAKI STASIUN DEPOK BARU)
}

\author{
Hobi Nur Ikhsan ${ }^{1}$, Winoto Hadi ${ }^{2}$, dan Yusfita Chrisnawati ${ }^{3}$ \\ ${ }^{1}$ Pendidikan Teknik Bangunan, FT, UNJ \\ ${ }^{2,3} \mathrm{D} 3$ Transportasi, FT, UNJ \\ Email: winoto@unj.ac.id
}

\begin{abstract}
ABSTRAK
Penelitian ini bertujuan untuk mengetahui tingkat aksesibilitas pejalan kaki Stasiun Depok Baru dari segi waktu. Metode penelitian ini menggunakan metode observasi. Penelitian ini akan memantau berapa lama pejalan kaki berjalan kaki dalam proses perpindahan moda transportasi dan menunggu moda lanjutan. Jumlah pejalan kaki yang diambil dari penelitian ini sebanyak 100 pejalan kaki dari 3 titik jalur jalan kaki yang tersedia yaitu Jl. Raya Margonda, Jl. Baru dan area pasar. Hasil penelitian ini menghasilkan nilai indeks aksesibilitas yang dihitung dengan metode Public Transportation Accessibility Levels (PTAL) berdasarkan jam dan moda lanjutan yang digunakan yaitu Kereta Rel Listrik (KRL) dan mobil angkutan kota (angkot). Hasil penelitian menunjukkan bahwa indeks aksesibilitas pejalan kaki pengguna moda KRL pukul 06.00 - 09.00 yaitu sebesar 8,36 dari Jl. Raya Margonda, dan 9,37 dari area pasar dan Jl. St. Depok Baru. Sedangkan indeks aksesibilitas pejalan kaki pengguna moda KRL pukul 09.00 - 12.00 yaitu sebesar 8,35 dari Jl. Raya Margonda, dan 5,14 dari Jl. Baru serta 5,00 dari area pasar. Untuk indeks aksesibilitas pejalan kaki pengguna moda mobil angkutan kota pukul 12.00 - 15.00 yaitu sebesar 36,45 menuju Jl. Raya Margonda, 36,46 mепијu Jl. St. Depok Baru dan 84,29 menuju area pasar. Sedangkan indeks aksesibilitas pejalan kaki pengguna moda mobil angkutan kota pukul 15.00 - 18.00 yaitu sebesar 27,35 menuju Jl. Raya Margonda, 45,36 тепији Jl. Baru dan 36,72 menuju area pasar. Secara keseluruhan tingkat aksesibilitas pejalan kaki Stasiun Depok Baru masuk dalam kategori buruk untuk moda KRL dan masuk dalam kategori sempurna untuk moda mobil angkot.
\end{abstract}

Kata kunci: Indeks aksesibilitas, PTAL, Perpindahan moda

\section{ABSTRACT}

This research aims to find out the accessibility levels for pedestrian in Depok Baru Stastion based on time. The method used is observation include with the desk approach. The research is to find out walking distance the pedestrian walking along transfer process for transportation mode. Number of pedestrians that will be taken as many as 100 pedestrians from 3 points. The result of this research will accessibility index (AI) score with Public Transportation Accessibility Levels (PTAL) which based on time and transportation mode (railway as commuter line and car public transport). The result showed accessibility index levels for commuter line at 06.00 - 09.00 is 8,36 (poor) from Raya Margonda, and 9,37 (poor) from market area and Jl. Baru. Accessibility indeks levels for commuter line at $09.00-12.00$ is 8,35 (poor) from Jl. Raya Margonda, 5,14 from Jl. Baru, and 5,00 from market area (very poor). Accessibility indeks levels for car public transport at 12.00 - 15.00 is 36,45 (excellent) to Jl. Raya Margonda, 36,46 (excellent) to Jl. Baru, and 84,29 (excellent) to market area. Accessibility index levels for car public transport at 15.00 - 18.00 is 27,35 (excellent) to Jl. Raya Margonda, 45,36 (excellent) to Jl. Baru, and 36,72 (excellent) to market area. Overall, accessibility index levels at Depok Baru Station is poor for commuter line and excellent for car public transport.

Keywords: Accessibility index, PTAL, Mode shift 


\section{PENDAHULUAN}

Stasiun Depok Baru memiliki jalur pejalan kaki. Terdapat 3 (tiga) jalur yang biasa dilewati oleh pejalan kaki yaitu di titik Jl. Raya Margonda, Jl. Baru dan area pasar. Secara jarak, ketiga jalur tersebut termasuk layak untuk dilewati. Namun, belum ada pengukuran aksesibilitas untuk mengetahui apakah dari segi waktu ketiga jalur tersebut layak untuk diakses atau tidak(Murtiningsih, 2009). Sama halnya dengan berjalan kaki, waktu tunggu moda transportasi juga menjadi faktor apakah transportasi tersebut layak diakses dari segi waktu atau tidak (Nathaniel F, 2017). Commuter line dan angkutan kota (angkot) di Stasiun Depok Baru memiliki waktu tunggu (headway) yang cukup baik. Commuter line memiliki jadwal kedatangan yang sudah terjadwal sehingga potensi headway yang tinggi cukup kecil. Menurut Budianto (2010) Berbeda dengan commuter line, angkot memiliki headway yang tidak tetap yang menyebabkan belum ada kejelasan jadwal kedatangan angkot. Secara keseluruhan, durasi berjalan kaki hingga menaiki moda transportasi lanjutan adalah satu kesatuan yang harus diperhatikan tingkat aksesibilitasnya. Hal ini bertujuan untuk mengetahui lebih rinci sejauh mana konektivitas antar moda transportasi umum terjalin dengan bagus.

Rute berjalan kaki yang cepat dan waktu tunggu moda transportasi umum lanjutan yang rendah membuat masyarakat lebih senang untuk menggunakan jasa transportasi umum. Kedua aspek tersebut bisa diukur dengan metode Public Transport Accessibility Levels (PTAL). Metode PTAL yang berasal dari London ini mengukur tingkat aksesibilitas pejalan kaki dari segi waktu berjalan kaki dan juga waktu menunggu moda transportasi (Maulani, 2010). Tingkat aksesibilitas dari PTAL akan tergambarkan berupa indeks yang memiliki kategori sangat buruk, buruk, cukup, bagus, sangat bagus dan sempurna. Metode PTAL sangat cocok diaplikasikan untuk mengetahui sejauh mana tingkat aksesibilitas pejalan kaki pengguna Stasiun Depok Baru. Public Transportations Accessibility Levels (PTAL) Aksesibilitas transportasi menjadi pertimbangan utama dalam perencanaan dan evaluasi fasilitas transportasi (BSN, 2009). Oleh karena itu pengukuran aksesibilitas transportasi umum menjadi sangat penting. London Borough of Hammersmith and Fulham membangun metodologi pengukuran level aksesibilitas transportasi umum bernama Public Transport Accessibility Levels (PTAL) dan diadopsi oleh Transport for London (TfL) untuk diaplikasikan di kota London (Abley \& Williams, 2008). PTAL mendetailkan dan mengukur aksesibilitas sebuah titik jalur pejalan kaki menuju jaringan transportasi umum dengan mempertimbangkan lama berjalan kaki dan ketersediaan layanan transportasi. Pengukuran model PTAL ini mendeskripsikan 4 unsur yaitu (Mauliani, 2010):

1. Lama berjalan kaki dari titik pengukuran ke titik akses transportasi umum;

2. Keandalan moda layanan transportasi yang tersedia;

3. Jumlah layanan moda transportasi yang tersedia;

4. Rata - rata waktu tunggu kendaraan umum (LoS of Public Transport) 
Tabel 1: Indikator PTAL

\begin{tabular}{llll}
\hline PTAL & Range of Index & Map Colour & Descriptio \\
\hline $1 \mathrm{a}($ Low $)$ & $0.01-2.50$ & & Very poor \\
$1 \mathrm{~b}$ & $2.51-5.00$ & & Very poor \\
2 & $5.01-10.00$ & & Poor \\
3 & $10.01-15.00$ & & Moderate \\
4 & $15.01-20.00$ & & Good \\
5 & $20.01-25.00$ & & Very Gooc \\
$6 \mathrm{a}$ & $25.01-40.00$ & & Excellent \\
$6 \mathrm{~b}$ (High) & $40.01+$ & & Excellent \\
\hline
\end{tabular}

(sumber: Transport for London)

Tabel di atas adalah 6 tingkatan pada PTAL. Jika nilai PTAL makin besar, maka tingkat aksesibilitas angkutan umum di kawasan tersebut bagus. Begitu juga sebaliknya, jika nilai PTAL kecil, maka tingkat aksesibilitas angkutan umum di kawasan tersebut buruk (Muchtar, 2010). Adapun proses pendataan untuk menghitung PTAL adalah sebagai berikut (Transport for London, 2010):

1. Tentukan titik awal pengamatan (Point of Interest)

2. Tentukan titik transfer moda (Service Access Point)

3. Tentukan jarak dan rute valid pejalan kaki antara titik awal pengamatan dan titik transfer moda

4. Catat waktu berjalan kaki (walking time) dari titik awal pengamatan ke titik transfer moda

5. Catat waktu tunggu pejalan kaki (waiting time) untuk mendapatkan moda lanjutan (angkutan umum, ojek, dsb.)

6. Hitung time headway dan frekuensi angkutan umum yang lewat di sekitar titik transfer moda sebagai alternatif waktu tunggu pejalan kaki mendapat moda lanjutan dan bisa menemukan average waiting time.
Aksesbilitas Pejalan Kaki... (Hobi/ hal. 76-84)

Setelah mendapat data dengan langkah - langkah di atas, maka bisa untuk menghitung indek aksesibilitas. Adapun langkah untuk menghitung indeks aksesibilitas adalah sebagai berikut (Transport for London, 2010).

1. Menghitung total access time (TAT)

TAT didapat dengan rumus sebagai berikut:

Total Access Time $=$ Walking Time + Average Waiting Time

Dalam mencari average waiting time juga bisa melakukan perhitungan sendiri pada setiap rute. Perhitungan ini akan menghasilkan scheduled waiting time (SWT) dengan rumus:

$\mathrm{SWT}=(\mathrm{K} / 2) \mathrm{X}(60 /$ Frekuensi $)$

Adapun $\mathrm{K}$ adalah reliabilitas faktor dari sebuah kendaraan berdasarkan asumsi waktu kehadiran. Satuan dari TAT adalah menit.

2. Menghitung equivalent doorstep frequency (EDF)

EDF didapat menggunakan rumus berikut:

$\mathrm{EDF}=30 / \mathrm{TAT}$

Nilai EDF ini akan menghasilkan indeks aksesibilitas untuk satu orang.

3. Menghitung Indeks Aksesibilitas (untuk satu moda transportasi)

Setelah mendapat nilai EDF untuk satu orang, maka akan didapat indeks aksesibilitas untuk satu moda transportasi dengan rumus:

$\mathrm{AI}_{\text {mode }}=\mathrm{EDF}_{\max }+(0,5 \mathrm{X}$ All other
$\mathrm{EDF})$

4. Menghitung Indeks Aksesibilitas (untuk semua moda transportasi)

Setelah mendapat nilai $\mathrm{AI}_{\text {mode }}$ maka bisa dihitung indeks aksesibilitas untuk satu jalur pejalan kaki dengan rumus: 


\begin{abstract}
$\mathrm{AI}_{\mathrm{POI}}=\sum\left(\mathrm{AI}_{\text {mode } 1}+\mathrm{AI}_{\text {mode2 }}+\right.$ $\mathrm{AI}_{\text {mode3 }} . . . \mathrm{AI}_{\text {mode }}$ )

Dari AIPoI selanjutnya akan dicocokan dengan tabel yang dibuat PTAL untuk menentukan kategori indeks aksesibilitas dari suatu jalur pejalan kaki.
\end{abstract}

\section{Metode Penelitian}

Penelitian dilakukan pada hari Senin tanggal 24 Juli 2017. Penelitian ini akan berlangsung selama 12 jam dari pukul 06.00 - 12.00. Target populasi serta unit sampel dalam penelitian ini adalah pejalan kaki yang menggunakan fasilitas Stasiun Depok Baru. Untuk jumlah sampel yang akan diambil untuk penelitian ini yaitu sebanyak 100 orang dengan rincian sebagai berikut.

Tabel 2: Rincian jumlah pejalan kaki berdasarkan titik pengamatan

\begin{tabular}{ccc}
\hline Jam & Rute & $\begin{array}{c}\text { Jumlah } \\
\text { (orang) }\end{array}$ \\
\hline \multirow{2}{*}{$06.00-$} & $\begin{array}{c}\text { Jl. Raya Margonda - } \\
\text { Stasiun }\end{array}$ & 10 \\
09.00 & Area Pasar - Stasiun & 10 \\
\cline { 2 - 3 } & Jl. Baru - Stasiun & 10 \\
\hline \multirow{2}{*}{$09.00-$} & $\begin{array}{l}\text { Jl. Raya Margonda - } \\
12.00\end{array}$ & 10 \\
\cline { 2 - 3 } & Stasiun & \\
\cline { 2 - 3 } & Area Pasar - Stasiun & 5 \\
\hline \multirow{3}{*}{$12.00-$} & Jl. Baru - Stasiun & 5 \\
\cline { 2 - 3 } 15.00 & $\begin{array}{c}\text { Stasiun - Jl. Raya } \\
\text { Margonda }\end{array}$ & 10 \\
\cline { 2 - 3 } & Stasiun - Area Pasar & 10 \\
\cline { 2 - 3 } $15.00-$ & Stasiun - Jl. Baru & 10 \\
\hline \multirow{2}{*}{18.00} & Stasiun - Jl. Raya & 10 \\
\cline { 2 - 3 } & Margonda & 5 \\
\cline { 2 - 3 } & Stasiun - Area Pasar & Stasiun - Jl. Baru \\
\hline
\end{tabular}

Metode pengambilan sampel untuk penelitian ini menggunakan metode simple random sampling di mana pejalan kaki akan dipilih secara acak untuk dicatat berjalan kakinya tanpa melihat usia, jenis kelamin dan faktor - faktor lain. Untuk teknik analisis data penelitian ini akan menggunakan teknik deskriptif statistik. Dengan teknik deskriptif statistik data pejalan kaki akan dihasilkan dalam bentuk grafik, diagram serta layout jalur pejalan kaki berdasarkan indeks aksesibilitas.

\section{HASIL DAN PEMBAHASAN}

Jenis Kelamin Pejalan Kaki

Hasil observasi menunjukkan bahwa pejalan kaki yang menuju Stasiun Depok Baru dalam satu hari terdiri dari $63 \%$ laki - laki dan $37 \%$ perempuan.

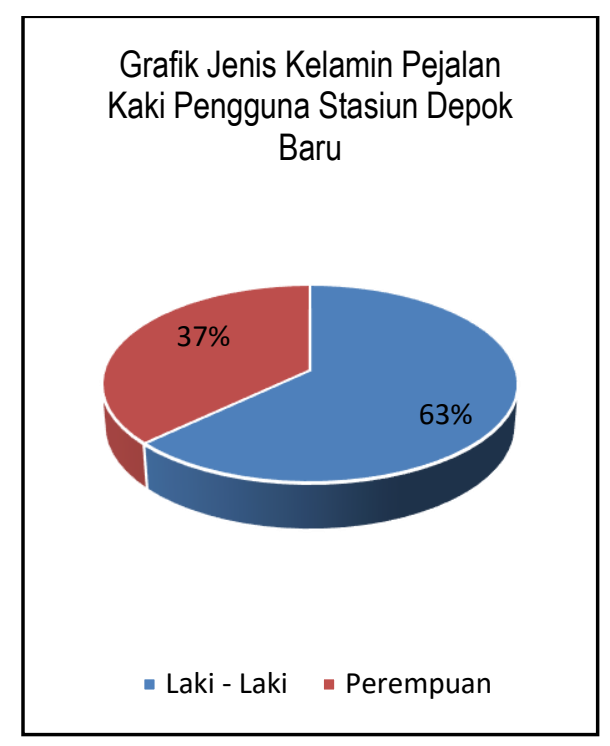

Gambar 1: Grafik jenis kelamin pejalan kaki

\section{Usia Pejalan Kaki}

Hasil observasi menunjukkan bahwa mayoritas pejalan kaki didominasi oleh pejalan kaki berusia 25 - 34 tahun dengan persentase $36 \%$ dari 100 orang pejalan kaki yang diamati. 


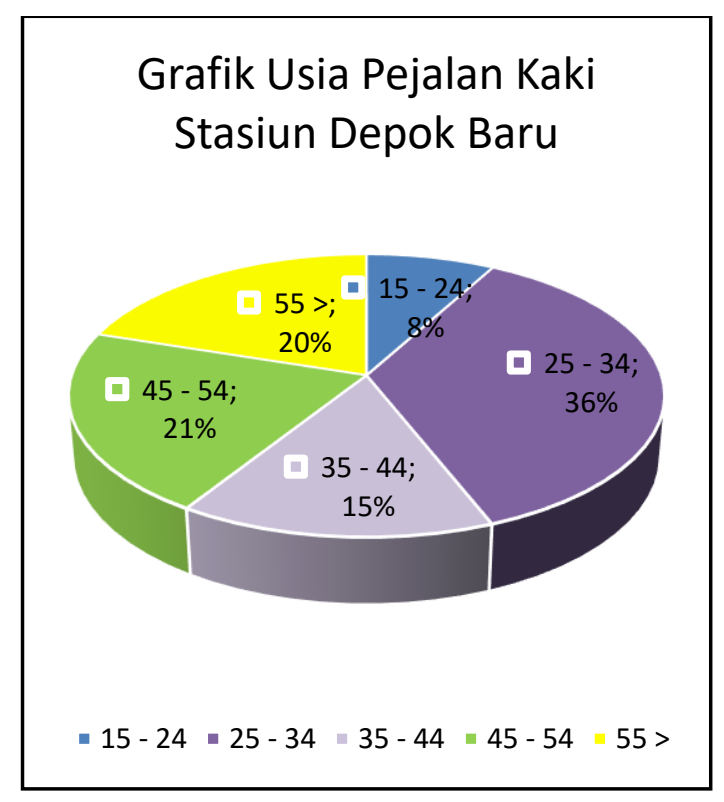

Gambar 2: Grafik usia pejalan kaki

Durasi Berjalan Kaki

Berdasarkan hasil observasi, dapat dideskripsikan beberapa data terkait dengan durasi berjalan kaki di Stasiun Depok Baru. Durasi berjalan kaki memiliki rata - rata berjalan yang variatif yang disebabkan faktor usia. Usia lebih tua biasanya cenderung lebih lama berjalan kaki ketimbang usia yang lebih muda.

Rata - rata durasi berjalan kaki dari arah jl. raya margonda menunjukkan laki laki cenderung lebih cepat berjalan kaki dibanding perempuan. Pada jam - jam tertentu perempuan lebih cepat berjalan kaki dibanding laki - laki. Pada jam 11.00 dan 15.00 pejalan kaki didominasi oleh perempuan berusia 25 - 34 tahun sedangkan laki - laki didominasi oleh kelompok usia yang beraneka ragam. Hal menyebabkan rata - rata durasi berjalan kaki perempuan lebih rendah dibanding rata - rata durasi berjalan kaki laki - laki. Di bawah ini adalah grafik dari durasi berjalan kaki dari titik Jl. raya margonda

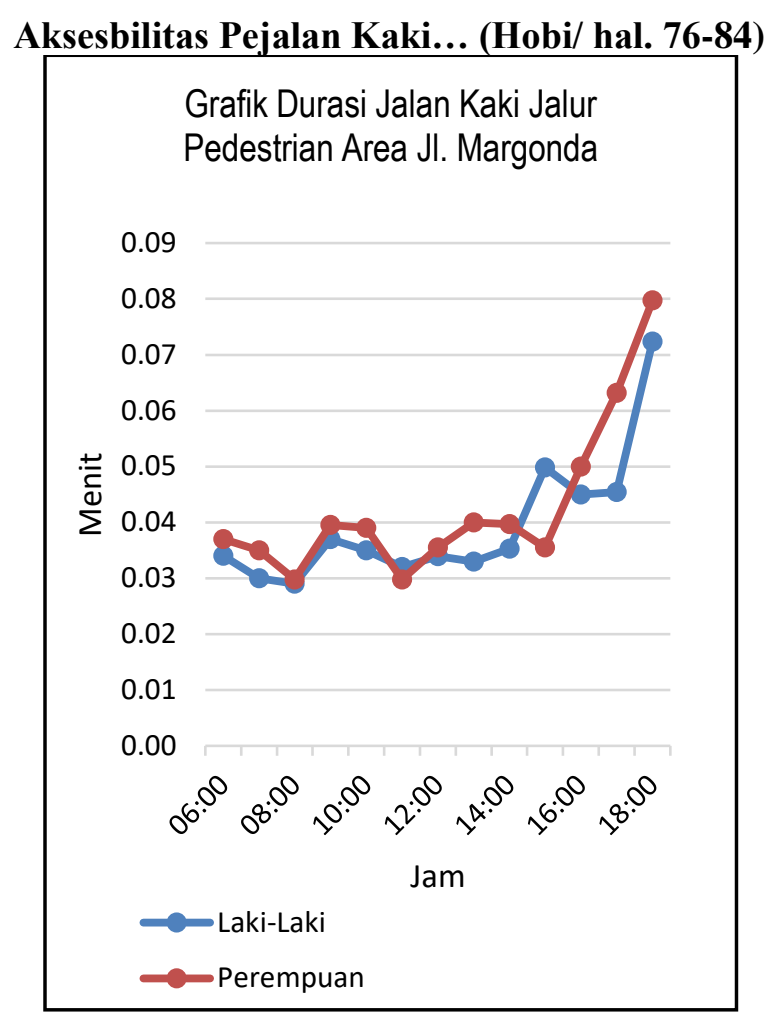

Gambar 3: Grafik durasi berjalan kaki titik jl. Margonda

Pada titik area pasar, juga menunjukkan secara keseluruhan laki laki lebih cepat berjalan kaki dibanding perempuan. Namun pada jam - jam tertentu perempuan lebih cepat berjalan kaki dibanding laki - laki. Pada jam 08.00 dan 14.00 pejalan kaki perempuan didominasi oleh kelompok usia 25 - 34 tahun, sementara pejalan kaki laki - laki didominasi oleh kelompok usia yang beraneka ragam. Di bawah ini adalah grafik durasi berjalan kaki dari titik area pasar. 
Aksesbilitas Pejalan Kaki... (Hobi/ hal. 76-84)

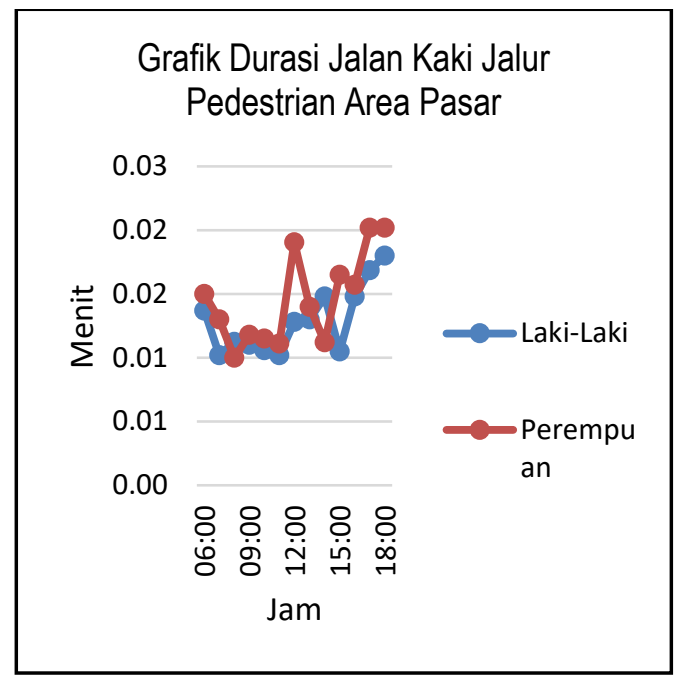

Gambar 4: Grafik durasi berjalan kaki titik area pasar

Pada titik Jl. baru menunjukkan rata - rata berjalan kaki laki - laki lebih cepat dibanding perempuan. Namun pada jam jam tertentu perempuan memiliki rata rata berjalan kaki lebih cepat dibanding laki - laki. Pada jam 11.00 rata - rata berjalan kaki perempuan lebih cepat dibanding laki - laki karena didominasi kelompok usia 45 - 54 tahun, sementara laki - laki didominasi pejalan kaki kelompok usia 55 tahun lebih. Pada jam 14.00 perempuan memiliki waktu berjalan lebih kecil dibanding laki - laki karena perempuan didominasi pejalan kaki usia 15 - 24 dan 25 - 34 tahun, sementara laki - laki didominasi pejalan kaki usia 45 - 54 tahun. Di bawah ini adalah grafik pejalan kaki di titik Jl. Baru

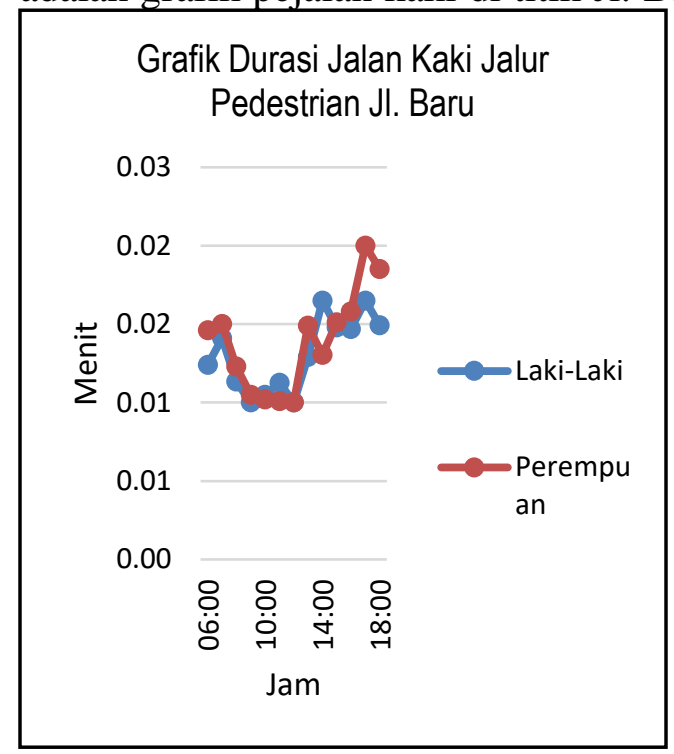

Gambar 5 : Grafik durasi jalan kaki jalur pedestrian Jl. Baru

Analisis Data Penelitian

Data headway bertujuan untuk menemukan nilai faktor reliabilitas kendaraan (K). Nilai K ini akan berguna untuk menghitung tingkat aksesibilitas berdasarkan moda transportasi. Dari hasil perhitungan headway kendaraan angkutan umum dan Kereta Rel Listrik, maka didapat headway sebagai berikut:

Tabel 3: Nilai faktor $\mathrm{K}$ mobil angkutan kota

\begin{tabular}{|c|c|}
\hline $\begin{array}{c}\text { Jumlah } \\
\text { Kendaraan }\end{array}$ & 68 \\
\hline $\begin{array}{c}\text { Rerata } \\
\text { Selisih }\end{array}$ & 1,41 \\
\hline
\end{tabular}

(sumber: pengamatan pribadi, Juli 2017) 
Tabel 4: Jadwal keberangkatan KRL jam $07.00-08.00$

\begin{tabular}{|c|c|c|c|}
\hline No & Kereta & Waktu & Selisih \\
\hline 1 & 1075 & 07.00 & 0 \\
\hline 2 & 1077 & 07.05 & 5 \\
\hline 3 & 1511 & 07.15 & 10 \\
\hline 4 & 1079 & 07.20 & 5 \\
\hline 5 & $1731-1732$ & 07.25 & 5 \\
\hline 6 & 1081 & 07.30 & 5 \\
\hline 7 & 1613 & 07.40 & 10 \\
\hline 8 & 1083 & 07.45 & 5 \\
\hline 9 & 1513 & 07.50 & 5 \\
\hline 10 & $1735-1736$ & 07.55 & 5 \\
\hline \multicolumn{3}{|c|}{ Nilai K (Rerata Selisih) } & 5,5 \\
\hline
\end{tabular}

(sumber: Gapeka, 2017)

Berdasarkan hasil selisih kendaraan (headway) diatas, frekuesi kehadiran (schedule frequency) dalam waktu 60 menit didapat angkutan umum sebanyak 68 kali dan KRL 10 kali. Selain itu didapat nilai selisih waktu kehadiran (K) untuk angkutan umum sebesar 1,41 untuk KRL sebesar 5,5. Maka akan didapat nilai average waiting time (AWT) yaitu:

Angkutan Umum $=(\mathrm{K} / 2) \quad \mathrm{X}$ $(60 /$ Sch. Freq $)=(1,41 / 2) \times(60 / 68)=$ 0,62 '

$\mathrm{KRL}=(\mathrm{K} / 2) \mathrm{X}(60 /$ Sch. Freq $)=$ $(5,5 / 2) X(60 / 10)=16,5$,

Berdasarkan deskripsi data pejalan kaki yang diamati, jumlah pejalan kaki didominasi oleh laki - laki dengan persentase $63 \%$ sedangkan perempuan 37\%. Untuk pejalan kaki berdasarkan usia paling banyak digunakan oleh kelompok pejalan kaki. usia 25 - 34 tahun dengan persentase $36 \%$. Sedangkan pejalan kaki paling sedikit berdasarkan usia
Aksesbilitas Pejalan Kaki... (Hobi/ hal. 76-84) didominasi oleh kelompok usia $15-24$ tahun dengan persentase $8 \%$.

Hasil faktor $\mathrm{K}$ yang diambil dari headway kendaraan dalam penelitian terbagi menjadi dua (2) moda. Moda yang digunakan adalah kereta rel listrik (KRL) dan mobil angkutan umum. nilai headway untuk KRL sebesar 5,5 dan mobil angkutan umum sebesar 1,41. Sehingga nilai rerata waktu tunggu (average waiting time / AWT) untuk KRL sebesar 16,5 menit dan mobil angkutan umum sebesar 0,62 menit.

Hasil indeks aksesibilitas pejalan kaki terbagi berdasarkan moda yang digunakan. Moda yang digunakan adalah KRL dan mobil angkutan umum. Untuk pejalan kaki yang menggunakan moda KRL dibagi berdasarkan jam, yaitu pada pukul 06.00 - 09.00 dan 09.00 - 12.00. Sedangkan pejalan kaki yang menggunakan moda mobil angkutan umum yaitu pada pukul 12.00 - 15.00 dan $15.00-18.00$. Untuk indeks aksesibilitas pejalan kaki pengguna moda KRL pukul 06.00 - 09.00 yaitu sebesar 8,36 dari J1. Raya Margonda, dan 9,37 dari area pasar dan Jl. St. Depok Baru. Sedangkan indeks aksesibilitas pejalan kaki pengguna moda KRL pukul 09.00 12.00 yaitu sebesar 8,35 dari Jl. Raya Margonda, dan 5,14 dari J1. St. Depok Baru serta 5,00 dari area pasar. Untuk indeks aksesibilitas pejalan kaki pengguna moda mobil angkutan kota pukul 12.00 - 15.00 yaitu sebesar 36,45 menuju Jl. Raya Margonda, 36,46 menuju J1. St. Depok Baru dan 84,29 menuju area pasar. Sedangkan indeks aksesibilitas pejalan kaki pengguna moda mobil angkutan kota pukul 15.00 - 18.00 yaitu sebesar 27,35 menuju Jl. Raya Margonda, 45,36 menuju Jl. St. Depok Baru dan 36,72 menuju area pasar. Berikut ini adalah tabel yang menjelaskan secara 
ringkas hasil indeks aksesibilitas pejalan kaki Stasiun Depok Baru.

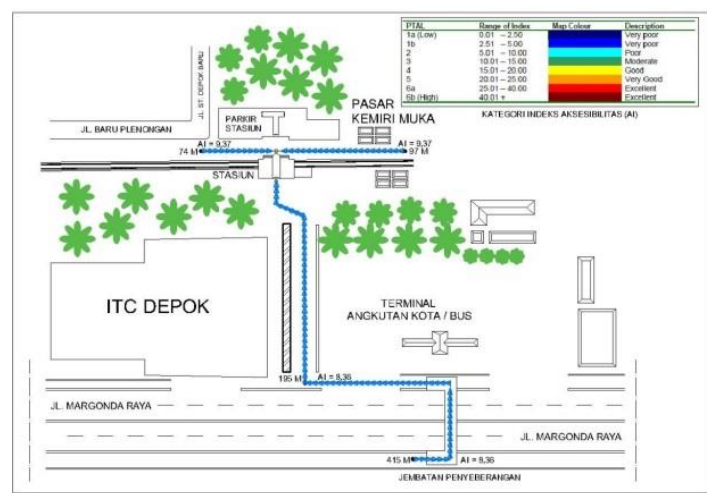

Gambar 6: Indeks aksesibilitas pukul 06.00 09.00

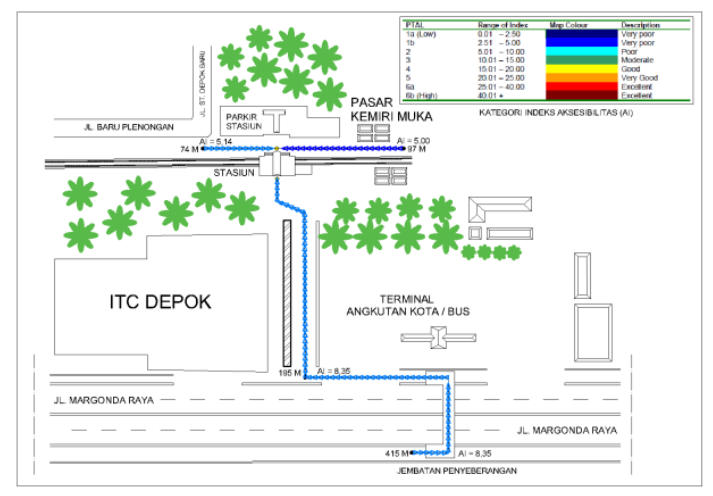

Gambar 7: Indeks aksesibilitas pukul $09.00-12.00$

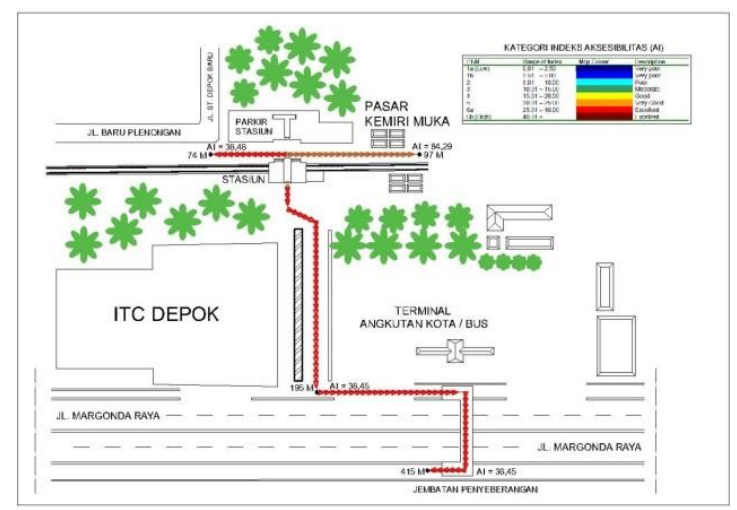

Gambar 8: Indeks aksesibilitas pukul 12.00 15.00

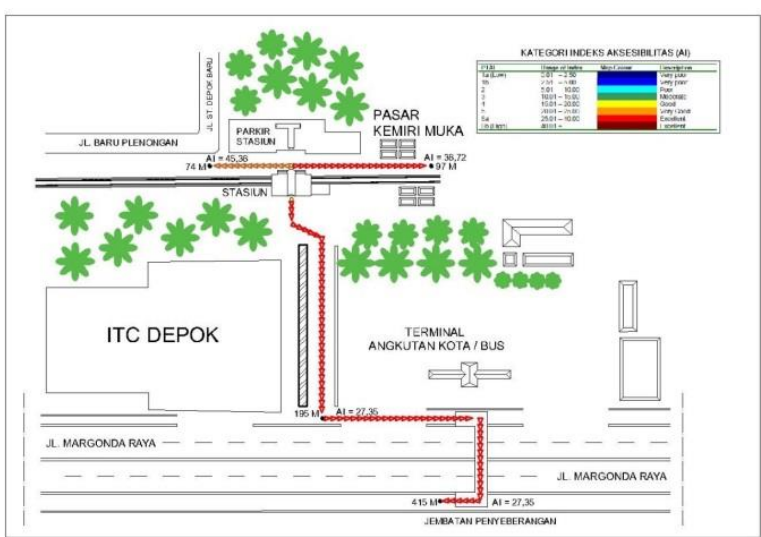

Gambar 9: Indeks aksesibilitas pukul 15.00 18.00

\section{KESIMPULAN}

Berdasarkan hasil analisa dan pembahasan maka dapat disimpulkan mengenai tingkat aksesibilitas pejalan kaki Stasiun Depok Baru sebagai berikut:

1. Berdasarkan indeks aksesibilitas dari PTAL, tingkat aksesibilitas pejalan kaki yang menggunakan moda KRL masuk kategori buruk. Hal ini terlihat dari nilai indeks yang masuk dalam deskripsi indeks sangat buruk dan buruk pada pukul 06.00 - 12.00 . Sedangkan tingkat aksesibilitas pejalan kaki yang menggunakan moda mobil angkot masuk kategori sempurna. Hal ini terlihat dari nilai indeks yang masuk dalam deskripsi indeks sempurna pada pukul 12.00 18.00 .

2. Rata - rata waktu tunggu (scheduled waiting time/SWT) moda KRL lebih lama dibanding moda mobil angkot dalam rentang 1 jam. Hal ini terlihat dari nilai SWT moda KRL sebesar 16,5 menit dan nilai SWT moda mobil angkot sebesar 0,62 menit. 
Selain itu, jumlah moda KRL yang tiba dalam rentang waktu 1 jam sebanyak 10 unit, sedangkan moda mobil angkot yang tiba dalam rentang 1 jam sebanyak 68 unit.

\section{SARAN}

1. Pihak pengelola KRL commuter line diharapkan bisa menambah jumlah

2. unit atau gerbong moda KRL untuk mengurangi waktu tunggu untuk moda lanjutan KRL.

3. Pihak dinas perhubungan diharapkan bisa meningkatkan kualitas jalur pejalan kaki khususnya fasilitas pendukung seperti peneduh untuk menghindari terik matahari dan hujan dalam rangka membantu pejalan kaki mengurangi durasi berjalan kaki yang tinggi terutama pada titik jalur pejalan kaki Jl. Raya Margonda yang menuju Stasiun Depok Baru

\section{REFERENSI}

Abley, S., \& Williams, R. (2008). Public Transport Accessibility Levels.

Transport for London. (2010). Measurng Public Transport Accessibility Levels. London.

Badan Standarisasi Nasional. 1991. Standar Nasional Indonesia (SNI) 03-2443- 1991 Spesifikasi Trotoar. Jakarta: BSN.

Budianto, E. 2010. Sistem Informasi Geografis dengan Arc View GIS. Yogyakarta: Andi Offset

Frans AJ, Tandobala L, Waani JO. 2016. Persepsi Pejalan Kaki Terhadap Keamanan dan Kenyamanan Jalur
Aksesbilitas Pejalan Kaki... (Hobi/ hal. 76-84)

Trotoar di Pusat Kota Amurang. Daseng: Jurnal Arsitektur, Vol. 5, No. 2, hal. 10-23.

Mauliani, L. 2010. Fungsi dan Peran Jalur Pedestrian bagi Pejalan Kaki. NALARs, Vol. 9, No.2, hal. 165176

Muchtar, C. 2010. Identifikasi Tingkat Kenyamanan Pejalan Kaki Studi Kasus Jalan Kedoya Raya - Arjuna Selatan. Planesa, Vol. 1, No.2, hal. 153-159.

Muslihun, M. 2013. Studi tentang Kenyamanan Pejalan Kaki terhadap Pemafaatan Jalur Pedestrian di Jalan Protokol Kota Semarang (Studi Kasus Jl. Pahlawan Semarang). Skripsi, Program Studi Pendidikan Teknik Bangunan, Fakultas Teknik Universitas Negeri Semarang.

Murtiningsih. 2009. Analisis Kinerja Saluran Drainase di Daerah Tangkapan Air Hujan Sepanjang Kali Pepe Kota Surakarta. Tugas Akhir, Jurusan Teknik Sipil, Fakultas Teknik Universitas Sebelas Maret, Surakarta.

Nathaniel, F. 2017. Hak Pejalan Kaki Di Trotoar yang Sering Terabaikan. [Online].(https://tirto.id/hakpejalan-kaki-di-trotoar-yangseringterabaikan-csNh), diakses pada 06 Maret 2019 